\title{
JEJAK SANG PENYAIR PERSIA: \\ CORAK SASTRA SUFISTIK JALALUDDIN MUHAMMAD MAULAVI \\ DALAM KARYANYA "MATSNAWI"
}

\author{
Rizqa Ahmadi \\ Jurusan Sastra Arab \\ Fakultas Sastra dan Seni Rupa \\ Universitas Sebelas Maret
}

\begin{abstract}
This paper analyzes sufistic literature of Jalaluddin Muhammad Maulavi through his works Matsnawi al-Ma'nawi. Based on analyze, this book not only contain basic principles of religion, but also contain other universal values. His view about unity of existence (wahdatul wujud) is the character of his thought about live and the existence of God. Love can deliver human in real peace and happiness. Besides, Maulavi has his own view about woman. Woman is people bring in positive and negative energy. The Sufis describes woman as creature having same ability with man. Although in certain phrase, he dramatizes woman position as despicable creature.
\end{abstract}

Keywords: sufistic, woman, wahdatul wujud, matsnawi, Isyq

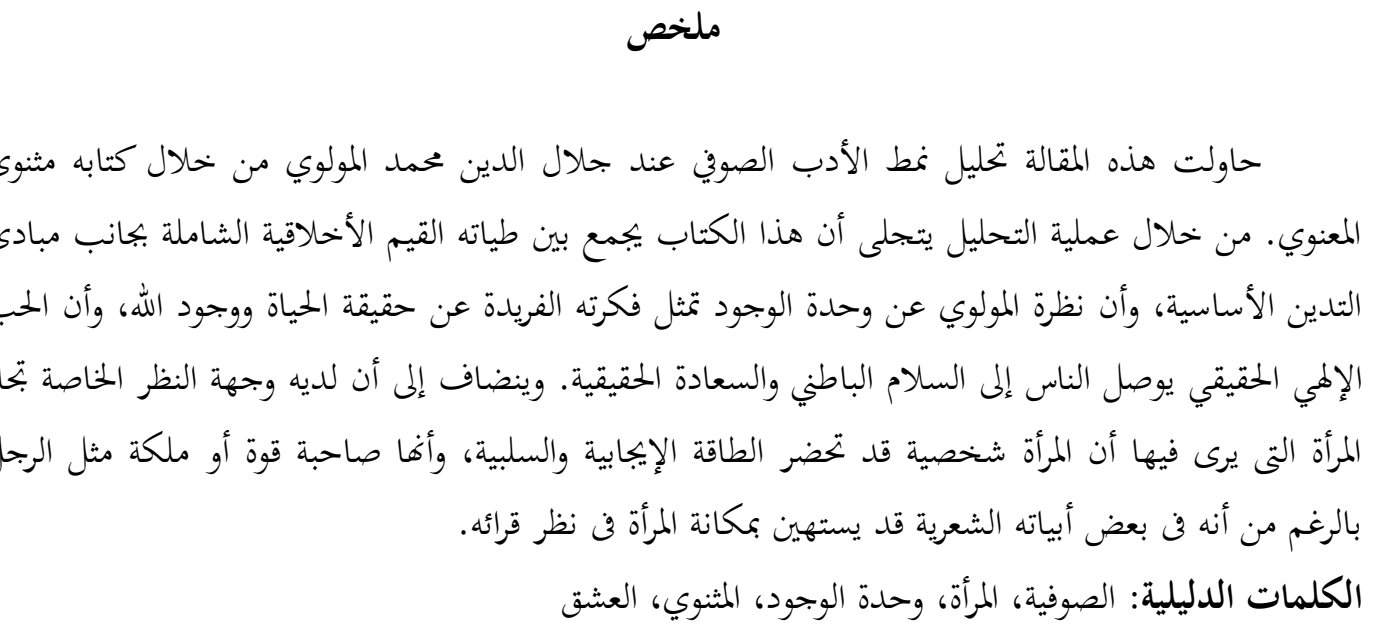

\section{Pendahuluan}

Sastra (Literature) merupakan ekspresi dan kreatifitas penciptaan. Dalam bahasa Indonesia, sastra biasa digunakan untuk merujuk kepada "kesusastraan" atau sebuah jenis tulisan yang memiliki arti keindahan tertentu. Dalam pengertian ini sastra juga dapat berupa lisan (oral) maupun tulisan. Umumnya sastra diklasifikasikan berdasarkan letak geografis maupun bahasa. Misalnya, sastra Nusantara, sastra Barat (meliputi Negaranegara barat dan jajahannya), Sastra Asia, dan sastra dunia. Sastra Nusantara dibagi lagi menjadi sastra Jawa, Sunda, Banjar, Melayu, Madura, Sasak, dan lainnya yang merupakann suku-suku di dalam wilayah nusantara. Begitu juga dengan sastra Asia, dibagi menjadi Sastra Asia Timur, Sastra Asia Barat, Sastra Asia Tengah, dan Sastra Asia Tenggara. Masing-masing ragam sastra tersebut memiliki corak dan karakteristik masing masing. Sebagai contoh Sastra Arab dan Persia yang termasuk dalam Sastra Asia Barat lebih condong pada sastra Islam. Sastra Islam 
biasanya didominasi oleh sastra sufistik, sastra prophetic (madaih) atau pujian kepada Nabi.

Menyoal sastra Islam memang tidak semua pakar sepakat bahwa sastra Islam termasuk salah satu bagian dari ragam sastra. AA. Navis merupakan salah seorang sastrawan yang menolak sastra Islam, dan menyebutnya sebagai hal yang utopis untuk saat ini. Diikuti oleh pendapat Edy A. Effendi. (www.id.wikipedia.org) menurutnya, sastra Islam tidak ada estetika yang diusungnya sehingga otomatis tertolak.

Kebalikan dari itu, Prof. Dr. Abdul Hadi WM. menyebut bahwa pandangan dan anggapan yang meragukan nisbah Islam dengan sastra dan kesangsian bahwa sastra Islam dengan tema, corak pengucapan, wawasan estetik serta pandangan dunia tersendiri, pada umumnya timbul untuk menafikan sumbangan Islam terhadap kebudayaan dan peradaban umat manusia. Sebagian anggapan berkembang karena semata kurangnya perhatian dari umat Islam dewasa ini terhadap sastra dan tiadanya apresiasi. Ditambahkannya, sastra Islam itu ada, bahkan eksis. Sastra Hindu saja ada, maka tidak masuk akal kalau sastra Islam dinafikan. (www.id.wikipedia.org) Faktanya di tingkat Internasional terbentuk Liga Sastrawan Muslim Sedunia. Organisasi ini dikenal juga dengan nama International League of Islamic Literature, atau dalam bahasa Arab menjadi Rabithah al-Adab al-Islami al-'Alamiyyah. Organisasi ini wadah sastrawan muslim yang berada di seantero dunia. Ini menandakan bahwa eksistensi sastra Islam sejatinya tidak diragukan lagi.

Sastra sufistik yang identik dengan sastra religius sampai era ini masih menarik diperbincangkan oleh para sarjana dan pemerhati sufisme internasional. Meskipun sebenarnya sastra sufi sendiri berbeda dengan sastra religius. Karena sastra religius adalah sastra yang memuat unsur-unsur keagamaan yang bersifat lebih umum, mencakup berbagai agama. Misal
Islam, Kristen, Hindu maupun agamaagama yang lain. Sedangkan sastra sufi lebih cenderung pada corak keislaman. Sastara sufistik muncul dipelopori oleh Ahli tasawuf.

Diantara pelopor munculnya sastra sufistik adalah para Penyair dari negeri Persia. Persia dikenal dengan para tokoh tasawuf yang memiliki karya-karya jika dikaji syarat akan nilai kesusastraan yang tinggi. Masih ingatkah dengan puisi berikut ini. Puisi ini dideklamasikan oleh Ayatullah Husna, salah seorang Aktris Film "Ketika Cinta Bertasbih" dalam sebuah adegan.

Cinta adalah kekuatan, yang mampu mengubah duri jadi mawar,

mengubah cuka jadi anggur, mengubah sedih jadi riang, mengubah amarah jadi ramah, mengubah musibah jadi muhibbah, itulah cinta.

Puisi di atas dikutip dari salah satu karya Sastrawan sekaligus Sufi ternama, Maulavi atau yang masyhur kita kenal dengan Jalaluddin Rumi. Ia adalah salah satu Sufi sekaligus Penyair dari Persia. Puisi tersebut tidak cukup jika diintepretasikan dengan makna cinta yang awam (baca: sederahana). Melainkan cinta di sini sangat kaya makna. Dalam pandangan Rumi, konsep Isyq (cinta) diartikan dengan cinta universal. Cinta menurut rumi bukan hanya milik mausia dan makhluk hidup lainnya, tetapi juga semesta. Cinta kepada Tuhan menarik perhatian semesta kepadanya, dan Tuhan menciptakan di dalamnya kerinduan untuk kembali dan bersatu. Ketika mabuk cinta mencapai puncaknya, perkawinan jiwa dalam penyatuan mistik terjadi. Dalam penyatuan inilah perbedaan antara pencinta dan kekasihnya sirna oleh perubahan ke dalam Hakikat Cinta universal.

Untuk mengkaji corak Jalaluddin Rumi dalam sastra sufistik, penulis membatasi kajian pada salah satu karya 
Rumi yaitu Matsnawi yang merupakan salah satu karya fenomenal sepanjang sejarah. Buku itu memuat dasar ajaran agama Islam, husunya tasawuf dan juga tentang falsafah hidup. Dengan kehebatan gaya bahasa yang digunakan, buku ini bernilai sastra dan layak untuk dikaji.

\section{Sejarah Sastra Sufistik Persia}

Sejarah awal mula sastra sufi berkaitan erat dengan sejarah tasawuf. Hal ini dikarenakan cakupan materi dalam sastra sufi pada umumnya adalah dimensi batin atau spiritual yang dipelopori oleh ahli tasawuf atau kita kenal Sufi. Sastra genre ini muncul bagian dari ekspresi Ketuhanan dan keagamaan para sastrawan kala itu.

Asal kata sufi secara harfiah sangat beragam. Al-Kalabadi berpendapat sufiyyah dinisbahkan pada lafadz sofa. Dikatakan Sufiyyah karena hati mereka bersih dan jernih. Pendapat yang lain menyebutkan, dinisbahkan pada jamaah ahli soffah, yaitu sahabat Nabi yang tinggal di ruangan yang berada belakang masjid Nabawi. Ada juga yang menisbahkan kata tasawuf pada sifat yang mulia dan jauh dari sifat tercela, atau juga dinisbahkan pada istilah Yunani Sofiya yang berarti hikmah. Sedangkan Ibnu Taimiyyah dan Ibnu Haldun menisbahkan kata sufiyyah pada kata souf yang berarti pakaian souf. .Mereka berpendapat demikian dengan alasan bahwa Para Nabi termasuk Nabi Muhammad SAW. memakai pakaian souf. Pakaian ini juga dipakai oleh para sahabat. Dan juga bahwa pakaian ini menandakan kerendahan hati dan tawadhu'. (Assyubki, 2002: 6) Ringkasnya, semua makna dari Tasawuf tersebut bermuara pada hakikat makna dari tasawuf. Yaitu proses pencarian menuju yang Maha bijaksana yang mana mustahil tahapan-tahapan itu bisa dilalui kecuali dengan hati yang bersih dan totalitas yang tanpa batas.

Sejarah Tasawuf kira-kira muncul pada abad ke 2 Hijriyah. Kelompk ini muncul sebagai antitesis dari kehidupan yang hedonis dan materialistis pada zaman itu. Khususnya yang terjadi pada kota-kota yang menjadi pusat perdagangan dan politik seperti Bagdad, Damaskus, Basra dan lain sebagainya. Cikal bakal munculnya golongan ini dipelopori oleh Ahli Zuhud atau kaum asketik yang hendak menepi dari kehidupan duniawi untuk memuaskan kerinduan dan hasrat kepada yang Maha menciptakan, melaksanakan ajaran Agama dengan totalitas. Di antara tokoh yang dipandang cikal bakal kelahirannya ialah ahli zuhud seperti, Hasan al-Basri, Makruf al-Karkhi, Rabi'ah al-Adawiyah, Hasan al-Muhasibi, Dhu alNun al-Misri, Sumnun, Hasan al-Nuri, dan lain sebagainya.

Perkembangan sastra Persia mencapai puncaknya pada abad ke 12 dan 13, bersamaan dengan berkembangnya ajaran tasawuf. Muncullnya para sastrawan yang bercorak sufi seperti, al-Busyairi, Fariduddin 'Attar dan Majduddin Sana'I adalah bagian dari capaian yang menjadi tonggak sejarah lahirnya sastra sufi Persia.

Salah satu satu karya sastra yang sampai saat ini masih dikenal oleh banyak orang adalah Alburdah karya, Al-Busyiri. Karya ini digolongkan pada genre sastra prophetic., atau dalam bahasa Arab almada'ih, dan na'tiyah dalam bahasa Persia. Wildana menyebutkan bahwa pada era ini almada'ih atau na'tiyah mencapai babakan baru, yaitu babakan sufistik, karena mendapatkan nafas tasawuf. Lahirnya karya karya mereka inilah yang membuat puisi almada'ih berkembang pesat dalam kesusastraan Islam. Khususnya karya al-Busyairi, selain sangat populer, ia besar pengaruhnya terhadap munculnya berbagai bentuk kesenian rakyat Islam. Karya al-Busyairi juga memberikan pengaruh yang tidak sedikit dalam metode dakwah Islam, pendidikan ilmu dan retorika ('ilm al-badi').(Wildana: 40)

\section{Ciri khas sastra Sufistik}

Mengamati karya-karya sastra sufistik dari awal kemunculannya di Arab 
dan Persia hingga tersebar ke berbagai benua dan penjuru dunia, tema-tema cinta Ketuhanan masih tetap mendominasi. Cinta Illahi memang menjadi jalan mulus untuk dapat menggapai tujuan kebahagiaan yang hakiki. Menurut para Sufi hakikat kehidupan harus dengan cinta. Bukan cinta biasa tetapi cinta yang mampu mengantarkan sang pecinta mengenal Tuhan dan dirinya. Mengutip perkataan Ibnu Arabi "Ada tiga bentuk pengetahuan. Pertama pengetahuan intelektual, yang dalam kenyataan berisi informasi dan kumpulan fakta-fakta serta teori belaka, dan apabila pengetahuan ini digunakan untuk mencapai konsep-konsep intelektual melampaui batasnya, maka ia disebut intelektualisme. Yang kedua, menyusul pengetahuan tentang keadaan-keadaan, mencakup baik perasaan emosional dan perasaan asing di mana orang mengira telah mencerap sesuatu yang tinggi. Namun orang yang memiliki ilmu ini tidak dapat memanfaatkan untuk keperluan hidupnya sendiri. Inilah yang disebut emosionalisme. Yang ketiga ialah pengetahuan yang disebut Pengetahuan tentang Hakikat. Pengetahuan ini membuat manusia dapat menyerap apa yang betul, apa yang benar, mengatasi bayasanbatasan pikiran biasa dan pengalaman empiris. Para sarjana dan ilmuwan memusatkan perhatian pada bentuk pengetahuan pertama. Kaum emosionalis dan eksperimentalis menggunakan bentuk kedua. Yang lain memadukan keduanya, atau memakai salah satu dari keduanya secara berganti-ganti. Akan tetapi orang yang telah mencapai kebenaran ialah mereka yang tahu bagaimana menghubungkan dirinya dengan hakikat yang terletak di balik kedua bentuk pengetahuan ni. Itulah sufi sejati, darwish yang telah mencapai makrifat dalam arti sebenarnya."

Walaupun bertolak dari tema pokok tunggal, yaitu cinta ilahi, tidak berarti karya Sufi tidak beranekaragam dan hanya mengungkapkan masalah kerohanian atau cinta transendental. Tidak jarang karya mereka mengandung kritik sosial; diantaranya sindiran terhadap kaum legalis formal dan ulama yang mengagungkan tafsir formal dan rasional terhadap ajaran agama. Karena itu tak mengherankan serangan terhadap Sufi pada umumnya datang dari mereka. Demikiakanlah yang diungkapkan dalam kesastraan sufi itu bukan semata-mata pengalaman dan keadaan jiwa yang dialami ahli suluk dalam menempuh jalan cinta dan makrifat; melainkan juga contoh-contoh dalam kehidupan individu dan masyarakat yang berkaitan dengan amal dan ibadah. Misalnya tentang ikhtiar dan perjuangan manusia yang tak kenal lelah mencapai kebenaran, serta godaan-godaan hawa nafsu yang sering tak dapat diatasi dengan akibat hatinya keruh dan penglihatan batinnya kabur terhadap hakekat ajaran agama.( www.jendelasastra.com)

\section{Biografi Maulavi dan karyanya "Matsnaw"}

Nama lengkap Maulavi adalah Jalaluddin Muhammad dan mashur dengan julukan Maulana atau Maulavi. Beliau lahir pada tanggal 6 Rabi'ul Awwal tahun 604 H. atau 30 September 1207 M. di kota Balkh yang merupakan bagian dari wilayah kerajaan Khwarizmi. Saat ini, kota tersebut adalah salah satu tempat di Afganistan. Dulu, pada zaman Maulavi, tempat itu sebagai pusat kebudayaan, sastra dan kepercayaan-kepercayaan Bangsa Iran.(Dasyuki, 1996: 6) Ia juga dikenal dengan nama Jalaluddin Rumi. Disebutkan juga dalam Al-a'lam, Khairuddin Azzirikli mengatakan, Jalaluddin Rummi adalah ahli fiqih hanafi dan berbagai ilmu. Ia adalah pengikut tasawuf (Sufi). Ia juga dikenal dengan pengarang buku Matsnawi yang masyhur di Persia dan penggagas Tariqah Maulawiyah yang dinisbahkan kepadanya. Ayah Rumi bernama Bahauddin Walad Muhammad bi Husain AL-Khotibi seorang ulama terkemuka di Balkh. Ia adalah pemimpin Tariqat Kubrawiyah. Ia dijulki dengan "Sulthonul 'Ulama" karena 
kedudukannya fitnahpun dituduhkan kepadanya. Sehingga ayah Maulavi wafat pada tahun $628 \mathrm{H}$.

Maulavi menghabiskan waktunya dalam pengembaraan. Sejak usia empat tahun, Mau lavi bersama ayahnya pindah ke Bagdad. Selain di Bagdad, Ia juga mengunjungi beberapa kota seperti Khurasan dan Naisabur. Ia sempat tinggal beberapa saat di kota-kota tersebut. Baru pada tahun $623 \mathrm{H}$. setelah sempat mengunjungi Makkah dan Damaskus, ia menetap di Kunya, Anatolia. Dengan kemampuannya menguasai fiqh dan syari'at Islam, ia mengajar di empat madrasah kota tempat ia tinggal. Pada kurun waktu 642 H. ia meninggalkan kegiatan mengajar dan mengarang dan lebih memilih menggeluti matematika, bermusik, dan menyusun bait-bait sya'ir dan mendeklamasikannya. Pada waktu inilah diantara karaya monumentalnya "Matsnawi" ditulis. (Al-Qunawi, 2000: 28)

Sebagai bagian dari tradisi para Ulama', Maulavi mewariskan banyak karya yang fenomenal. Diantara karya Maulavi yang paling legendaris adalah buku syair dalam bahasa Persia berjudul "Matsnawi Ma'nawi." Atau juga dikenal dengan "Matsnawi". Buku ini terdiri dari dua puluh lima ribuan bait syair, terbagi menjadi 6 juz. Buku ini ditulis berkat keinginan muridnya sekaligus sahabtanya, Husamuddin. Karena puisi-puisinya menggunakan kata-kata Persia yang sukar dicari padanannya dalam bahasa lain, para penerjemah menyalin puisi Rumi menjadi gaya bebas, prosa, prosa liris, puisi, atau lagu, atau gabungan dari semuanya. Sebagian Ilmuwan menyebut buku ini sebagai tafsir al-Quran dengan pendekatan tasawuf. Selain Matsnawi, dia juga menulis sejumlah buku lainnya seperti, Divan-Syamsi-i-Tabriz, Fihi Ma Fihi, Maktubat Maulana, Majalis-i-Sab`ah, dan Ruba'iyati. Selain itu dua karya Maulavi, yakni Matsnawi dan Ghazaliyat dianggap sebagai salah satu maha karya umat manusia sampai saat ini. Buku-buku tersebut telah diterjemahkan ke berbagai bahasa dan telah tersebar ke berbagai penjuru dunia.

Maulavi wafat pada tanggal 5 Jumadil Tsani tahun 672 hijriah, di kota Konya, yang kini termasuk ke dalam wilayah Turki. Dia adalah penyair paling legendaris dunia Islam abad ketujuh hijriah. Kemampuannya dalam menyusun bait-bait syair, serta makna irfani yang terkandung di dalamnya, hingga kini masih menjadi bahan kajian para kritikus sastra dunia.

\section{Gaya bahasa Maulavi dalam "Matsnawi"}

Di dalam kitab Matsnawi, Maulavi dalam menuliskan bait-bait syairnya lebih sering mengunakan gaya sindiran bukan terang-terangan. Sebelum menyampaikan pesan biasanya dimulai dengan kisahkisah. Baik kisah itu bersumber dari kisah Islam maupun kisah yang dialami oleh sang Penyair dimana ia tinggal. Tidak jarang Maulavi juga menyampaikan pesanpesan syairnya melalui kisah kisah binatang.

Selain itu Rumi juga dikenal dengan penyair yang sering menggunakan gaya bahasa metafora (perbandingan). Kang Jalal menyebutnya sebagai Penyair yang Mahir menggunakan metafora. Orang Persia menyebutnya zarbul matsal. Dalam Matsnawi, Rumi mengajak kita berpikir analogis dengan mengambil ilham dari cerita-cerita di dalamnya. Matsnawi adalah kumpulan metafora yang indah. Pada hampir setiap kalimat Rumi menyadarkan kita akan kealpaan dan kekeliruan kita dengan cara yang sangat elegan. Ia mengusik kita dengan sejumlah metafora. Ia membuat kita termenung lama dengan perumpamaaan dan perbandingan yang dibuatnya. Kita disentuh dengan halus, tidak melalui akal rasional kita. Ia menyentuh akal spiritual kita. (Rahmat: 2001)

Di dalam syarakh Matsnawi berbahasa Arab, Dasuki Syatta menyebutkan penamaan kitab ini selain Matsnawi juga Ma'nawi. Hal ini 
dimaksudkan bahwa membaca Matsnawi memang membutuhkan pemahaman yang lebih. Untuk dapat mengetahui makna di balik ungkapan-ungkapan Rumi yang puitis.

Untuk menemukan metafora dalam sajak Rumi tidak sulit. Hampir di semua baitnya bisa ditemukan. Sebagai contoh, Pada Jilid ke dua kitab Matsnawi bait 1416-1429, Bahasa Indonesianya kurang lebih seperti berikut:

\section{Kambing Berlutut dan Bebek Lautan: \\ Kambing Berlutut Batin manusia seperti rimba. Kadang-kadang serigala berkuasa, terkadang babi- babi liar. Berhati-hatilah ketika kamu bernafas. \\ Sekali waktu sifat yang lembut dan pemurah bagaikan Yusuf, berganti menjadi sifat yang lain. Pada waktu yang lain, sifat-sifat yang jahat bergerak secara tersembunyi.}

Kearifan bergeser sejenak menjadi sapi! Kuda yang meradang dan membangkang tiba-tiba menjadi tunduk dan patuh. Beruang mulai menari, kambing berlutut!

Kesadaran manusia berubah menjadi anjing, dan anjing menjadi gembala, atau pemburu. Di Gua Ashabul Kahfi, bahkan anjing pun menjadi pencari makrifat.

Setiap saat, makhluk baru bangkit di dalam dada -kadang setan, kadang malaikat, kadang binatang buas. Bahkan di rimba yang menakjubkan ini ada mereka yang dapat menyerapmu ke dalam kepasrahan mereka sendiri. Jika kamu harus mencuri sesuatu, curilah dari mereka.

Dua kisah di atas merupakan nasihat Rumi agar kita mengenal diri kita terlebih dahulu, sebelum dapat mengenal Tuhan.

\section{Konsep Wahdatul wujud dan Cinta Universal}

Manunggaling kawulo gusti (kesatuan eksistensi) seperti yang digagas oleh Syeikh Siti Jenar merupakan bagian dari corak pemikiran para Ahli Tasawuf. Hal ini tentu saja sedikit terdengar aneh jika yang memahami adalah orang awam atau Teolog. Mulyadi kartanegara mempertegas hal ini dengan pernyatannya. Bahwa cara pandang sufi terhadap eksistensi memang agak berbeda dari kaum teolog (mutakalimun). Bagi kaum Sufi, eksistensi (wujud) berarti kenyataan/kebebnaran (haqiqah), dan tiada yang haqiqi kecuali kenyataan/kebenaran tertinggi. (Mulyadi, 2004: 15) Begitu juga dengan Maulavi. Ia menyuarakan gagasan tentang wahdatul wujud melalui syairsyairnya. Menurutnya kesatuan hamba dengan Tuhan, dipatrikan oleh rasa cinta yang murni, menghadapi perjuangan hidup dengan hati yang besar dan insyaf akan "tempat asal mula jadi". Inilah inti tasauf Rumi.

Sejauh ini bagi orang yang menilai Sufi dari luar, usaha untuk memahami konsep kesatuan Eksistensi memang butuh usaha yang keras. Makanya tidak sedikit orang yang menghukumi para sufi sebagai kaum yang murtad dan kafir. Padahal mestinya harus lebih berhati-hati jika kita belum mengalaminya sendiri. Ijtihad penulis mengindikasikan bahwa menurut para sufi wahdatul wujud sejatinya bukan berarti menyatunya dzat Tuhan dengan makhluknya (hulul) yang dapat mengarah pada penyekutuan Tuhan. Melainkan makhluk akan kembali ke sang pencipta setelah kematian. Karena hanya Tuhan satu-satunya yang memiliki sifat qadim dan baqa.

Mengutip pendapat Hamka sebagai penguat argumen penulis. "Alam itu menempuh tingkat kemajuan (evolusi), sepintas lalu kita melihat teori evolusi Rumi berdekatan dengan teori. Kaum materialis. Hanya saja, Rumi mengakui adanya Tuhan atau semuanya di dalam Tuhan dan kaum materialis tidak mengakui adanya Tuhan sama sekali. Rumi berpendapat bahwa maut itu tidak usah di takuti dan bukanlah persoalan yang berat. Mati hanya semata-mata perpindahan dari 
suatu tingkat ke tingkat yang lain. Yakni perpindahan atau menuju fanna ke dalam Tuhan yang disebut wahdatul wujud memandang kesatuan segala dalam ujud."(Hamka, 1994: 167)

Berikut ini kutipan pusi Maulavi yang mengusung tema wahdatul wujud.

Aku telah menyingkirkan dualitas, aku lihat dua dunia menyatu;

satu yang kucari, Satu yang kutahu, Satu yang kulihat, Satu yang kusebu.

"Dia yang Pertama,Dia yang Terkahir, Dia yang lahir, Dia yang Batin".

Aku tidak tahu kecuali "Ya Hua" dan "Ya Man Hua".

Aku mabuk oleh cangkir Cinta, dua dunia telah sirna dari

Pengetahuanku.

Selain pandangan Rumi tentang wahdatul wujud. Ia juga berpandangan bahwa cinta adalah asas penciptaan alam semesta dan kehidupan. Cinta adalah keinginan yang kuat untuk mencapai sesuatu, untuk menjelmakan diri. Rumi malahan menyamakan cinta dengan pengetahuan intuitif. Secara teologis, cinta diberi makna keimanan, yang hasilnya ialah haqq al-yaqin, keyakinan yang penuh kepada Yang Haqq. Cinta adalah penggerak kehidupan dan perputaran alam semesta. Cinta yang sejati dan mendalam, kata Rumi, dapat membawa seseorang mengenal hakikat sesuatu secara mendalam, yaitu hakikat kehidupan yang tersembunyi di balik bentuk-bentuk formal kehidupan. Karena cinta dapat membawa kepada kebenaran tertinggi, Rumi berpendapat bahwa cinta merupakan sarana manusia terpenting dalam menstransendensikan dirinya, terbang tinggi menuju Yang Satu. (www.sufiroad.blogspot.com)

\section{Wanita dalam pandangan Rumi}

Tema perempuan sekalipun dalam karya-karya Maulavi khususnya Matsnawi tidak dibahas secara khusus dalam bab tersendiri, namun pada bait-bait syair yang ditulisnya terkesan memiliki tempat tersendiri. Hal ini terbukti seperti ketika ia mengekspresikan perasaannya melalui gambaran tentang wanita-wanita terkenal seperti Hawa, Bilqis, Asiyah, Halimah, 'Aisyah, Zulaikha istri nabi Nuh. Sang sufi mencoba memberikan gambaran tentang perempuan secara obyektif. Artinya Maulavi mengilustrasikan seorang wanita dengan segala potensi yang dimilikinya baik positif maupun negatif.

Berikut ini beberapa kutipan baitbait Maulavi yang menggambarkan sisi positif wanita:

1. Ketika menggambarkan Hawa, istri Nabi Adam as.
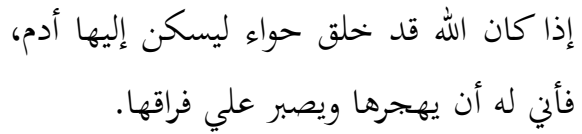

Jika Allah telah menciptakan Hawa untuk bersemayamnya Adam, maka ia berat untuk meninggalkannya dan bersabar berpisah dengannya

2. Gambaran tentang Ratu Bilqis

$$
\begin{aligned}
& \text { رحمة الله على بلقيس مائة مرة تلك التي } \\
& \text { حبها ربها عقل مائة رجل. }
\end{aligned}
$$

Kasih sayangg Allah kepada Bilqis serats kali lipat yang cintanya pada Tuhannya menahan cinta seratus laki-laki

3. Aisyah

$$
\begin{aligned}
& \text { ذاك الذي كان العالم عبدا لأقواله، ما أنفك } \\
& \text { يردد: كلموني يا حميراء. }
\end{aligned}
$$

4. Perbincangan Khalifah dengan laili 


$$
\begin{aligned}
& \text { قال الخليفة لليلي أنتت التي هام بها المخنون } \\
& \text { وغوي؟ لست أجمل من باقي الجميلات، } \\
& \text { فقالت له اسكت } \\
& \text { إنما نقول هذا لأنك لست بجنونا. }
\end{aligned}
$$

Khalifah berkata kepada Laili apakah kamu yang dicintai oleh orang gila dan berhasrat? Engkau tidak lebih cantik dari kecantikankecantikan yang lain. Maka Laili berkata kepada Khalifah: Diamlah sesungguhnya saya berkata demikian karena engkau bukan orang gila.

Selain Maulavi menggambarakan wanita dengan gambaran yang positif, ia juga menuliskan bait-bait syair yang bermuatan negatif. Bahkan terkadang terkesan mendiskreditkan wanita. Misalnya, ia menganggap bahwa kasus kriminal yang pertama ada di bumi adalah karena ulah wanita. Dalam syairnya ia berucap:

$$
\text { دام سال في عالم الظلم والعدل، كان علي }
$$

Darah yang dialirkan di dunia kegelapan dan keadilan dilakukan oleh Qobil untuk (merebutkan) wanita.

Contoh lain tentang penggambaran wanita sebagai subjek keburukan adalah ketika ia menyebutkan Zulaikha sebagai seorang wanita yang memiliki tipu muslihat.

يستنزل الروح من العرش إلي الحطام، إن كيد النساء

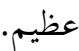

Diturunkanlah ruh dari Arsy ke dunia, sesungguhnya tipu muslihat wanita itu besar.

Dari beberapa kutipan bait syair di atas, melalui kisah-kisah wanita terkenal dalam Islam, Maulavi mencoba memaparkan dua sisi positif dan negatif wanita berdasar. Ia juga mencoba memaparkan kedudukan wanita dan hubungannya dengan laki-laki dalam keluarga. Menurut Rumi laki-laki mestinya bisa mengimbangi sifat wanita jika ingin segala urusan dapat mendatangkan maslahat. Ia juga mengibaratkan wanita laksana bayangan kebenaran Tuhan dan bukan hanya sebagai makhluk yang dicintai laki-laki. Bahkan bukti bahwa Maulavi tidak memojokkan peran wanita, ia membenci perbuatan kasar terhadap wanita.

\section{Kesimpulan}

Dari uraian di atas dapat disimpulkan bahwa secara metodologis, Matsnawi adalah sebuah karya sastra sufistik yang ditulis berdasarkan pengalaman spiritual sang penyair. Seperti kata Whinfield, salah seorang penerjemah karangan Rumi dalam bahasa Inggris, bahwa Matsnawi merupakan pemaparan tasawuf eksperiensial atau yang dialami secara langsung oleh pengarangnya. Ia bukan merupakan uraian tentang apa dan bagaimana tasawuf. Dalam karya agungnya itu Rumi menyebarkan pemikiran, gagasan dan perenungannya dalam untaian karangan bersajak yang indah, menggunakan metafora (ishti ara), tamsil dan kias. Namun sayangnya buku tersebut tidak tersusun secara sistematis dan runut seperti halnya karya-karya Sufi yang lain.

Adapun dari segi konten (isi), di dalam Matsnawi, Maulavi mewakili kaum sufi lainnya menyuguhkan pandangan yang brbeda tentang arti sesungguhnya kehidupan. Di tengah gersangnya jiwa, Ia merumuskan konsep cinta sejati yang universal. Di dalam Matsnawi terkandung nilai-nilai agung dalam menghayati keagamaan. Cinta memiliki kedudukan yang tinggi. Bahkan untuk bisa sampai suluk dan ma'rifat harus dengaun jalan cinta. Jadi untuk memahami kehidupan dan asal-usul Tuhan tidak mesti dengan ilmu pengetahuan melainkan dengan cinta. 
Dengan jalan cinta itulah menurut Rumi, manusia bisa menuju tempat tertinggi.

Selain berbicara tentang prinsipprinsip dasar kehidupan beragama dan bagaimana mengenal Tuhan dengan jalan cinta, di dalam Matsnawi, wanita merupakan bagian dari salah satu objek sastra yang tertuang dalam bait-bait karangannya. Maulavi memberikan gambaran yang komperhensif tentang wanita. Di satu sisi wanita adalah bayangan kebenaran Tuhan yang tidak pantas jika hak-haknya dirampas. Di sisi lain Maulavi berpendapat bahwa wanita adalah sumber dari keburukan, ia juga lambang dari hawa nafsu, Akalnya tidak sempurna, dan jiwanya rapuh. Wallahu a'lam.

\section{Daftar Pustaka}

Abu Khudzoiri, 'arif Karokhi. 2010. Tadris Al-Adab Al-'Arabi Lighoiri al'Arabi, Attariqah wal Hadf. Kairo: Maktabah al-Adab.

AL-Qunawi, Abul Fadl Muhammad bin 'Abdullah. 2000. Akhbar Jalaluddin Arrumi. Madinah Munawwarah.

Assyubki, Mahmud Yusuf. 2002. Mafhumu Tasawwuf wa Anwa'uhu fi Mizani Assyar'i. Edisi ke dua, Majalah Al-Jami’ah Al-Islamiyyah.

Hamka. 1994. Tasauf Perkembangan \& Pemurniannya. Jakarta: Pustaka Panjimas.

Isytihardi, Muhammad Al-Muhammadi. 1998. Qisos Matsnawi. Libanon: Dar al-Mahabbah Baidho.

Kartanegara, Mulyadi. 2004. Jalal Al-Din Rumi Guru Sufi dan Penyair Agung, Jakarta: Teraju.

Osman Haji Khalid. 1997. Kesusasteraan Arab Zaman Abasiah. Andalus dan
Zaman Modern. Kuala Lumpur: Dewan Bahasa dan Pustaka.

Rumi, Jalaluddin. 2001. Kitab Fihi ma Fihi Ahadits Maulana Jalaluddin AlRumi. Libanon: Dar al-Fikr Mu'asir.

Rumi, Jalaluddin. 2002. Almatsnawi. Kairo: Majlis A'la Li attsaqofah.

Rumi, Jalaluddin. 2004. Classic Poetri Series, Meulana Jalaluddin Rumi. Poemhunter.com-The Word Poetry Archive.

Shah, Idries. 1999. The Way Of The Suffi. Surabaya: Risalah Gusti.

Whinfield, 2001. Masnavi I Ma'navi Teaching of Rmmi: The Spiritual Couplet of Maulana Jalaluddin Muhammad I Rummi. Lowa: Omphalokepsis.

Zirikli, Khairuddin. 2002. Al-A'lam, Qomus Tarajum. Beirut: Darul 'Ilmi Lil Malayin. 